\title{
Elektromagnetiese modelle vir elektriese spoorbaanstelsels
}

\author{
B.M. Stcyn* en J.D. van Wyk** \\ Navorsingsgroep Industriële Elcktroniese Tegnologic, Fakultcit Ingenicurswese, Randse Afrikaanse Universitcil, \\ Posbus 524, Aucklandpark, 2006
}

Ontrang 20 September 1996; aanvatr 28 November 1996

\section{UITTREKSEL}

By die bestudering en die ontwerp van spoorstroombane is betroubare elektromagnetiese modelle van kardinale belang. Hieronder is modelle vir die bestudering van die werking van die verskillende tipes spoorstroombane, sowel as modelle vir die berekening van die invloed van steurings op die spoorstroomban. Enige van hierdie modelle het egter 'n aantal insette, wat as bekend beskou word, nodig. Die vernaamste hiervan is die primêre transmissielynkonstantes van die spoorbaan en die verspreiding van trekkragstrome in die spore. Modelle wat vir hierdie parameters gevind is, word bespreek voordal daar oorsigtelik na sekere van die genoemde spoorstroombacinmodelle gekyk word.

\section{Abstract}

\section{Electromagnetic models for electric track circuit systems}

The use of electromagnetic models is very expedient when railway track circuits are designed or when their operation is being studied. These electromagnetic models include models for performance analysis of the different types of track circuits as well as models used to study the effect of electromagnetic interference. Before these models can produce useful results they all require accurate input parameters. These parameters include the transmission line parameters of the track and the traction current distribution along the length of the track. Models that have been developed for these parameters are presented in this paper, together with an overview of the available track circuit models.

\section{Iys van simbole}

a

$a_{k, 4} \quad$ Radius van die geleiers

$2 \mathrm{~h} \quad$ Dic afstand tussen dic spore

D Helfte van die afstand tussen die substasic en dic lokomoticf in meler

$h_{k, 4} \quad$ Hoogte van geleiers $k$ en $q$ bokant dic aarde

$I_{1}=I_{s} \quad$ Lokomoticl of substasiestroom onderskeidelik

$\mathrm{I}_{1 \mathrm{~b}}, \mathrm{I}_{2 \mathrm{~h}} \quad$ Die strome in die onderskeic spore by die bron

$I_{1 r}, I_{2 r} \quad$ Die strome in die onderskeie spore by die ontvanger

$I_{\text {bk }} \quad$ Die stroom in dic trekkragspoor, wat vanaf dic aangrensende seksie by die spoorstroombaan invloei

$I_{r k} \quad$ Die stroom in die trekkragspoor, wat na die aangrensende seksie by dic spoorstroombaan uitvloei

1, Dic stroom in spoor 1

$\mathrm{l}_{2}$ Die stroom in spoor 2

$J_{0} \quad$ Besselfunksic

$J_{1} \quad$ Besselfunksic

$V_{1} \quad$ Dic spoor-aardspanning van spoor I

$\mathrm{V}_{2} \quad$ Dic spoor-aardspanning van spoor 2

$\mathrm{V}_{1} \quad$ Die spannings wat in dic onderskeic spore deur dic strome in die bobaan en die spore van die tweede lyn geïnduseer word

$V_{1 b}, V_{2 h}$ Die spoor-aardspanning van die onderskeie spore by dic bron

$\mathrm{V}_{1 \mathrm{r}}, \mathrm{V}_{2 \mathrm{r}}$ Die spoor-aardspanning van dic onderskeie spore by dic ontvanger

$\mathrm{Y}$ Die admittansic vanaf dic gegewe spoor na die aarde

$Z_{s 1} \quad$ Dic sellimpedansic van spoor nommer 1

$\mathrm{Z}_{s 2} \quad$ Dic sellimpedansic van spoor nommer 2

$\mathrm{Z}_{12} \quad$ Die wedersydse impedansie by spoor 1 as gevolg van die stroom in spoor nommer 2

$\mathrm{Z}_{21} \quad$ Die wedersydse impedansie by spoor 2 as gevolg van dic stroom in spoor nommer 1

$\mathrm{Z}_{\mathrm{h}} \quad$ Die ekwivalente bronimpedansie

$\mathrm{Z}_{\mathrm{r}} \quad$ Dic ekwivalente ontvangerimpedansic

$\mathrm{Z}_{\mathrm{i}} \quad$ Die interne impedansic van die spoor

$\mathrm{Z}_{\mathrm{x}} \quad$ Eksterne impedansie van die geleieraardlus

$\mathrm{Z}_{\mathrm{m}} \quad$ Wedersydse impedansic tussen die twee geleiers

$\mathrm{Z}_{0} \quad$ Karakteristieke impedansic $=\sqrt{\frac{\sqrt{k}}{6}}$

$\sigma_{1} \quad$ Dic geleidingsvermoë van die spoor

$\gamma_{1} \quad$ Dic voortplantingskonstante

$\mu_{1} \quad$ Permeabiliteit van die spoor

$\varepsilon_{1} \quad$ Permittiwiteit van die spoor

$\omega \quad$ Die hoekirekwensic

$\sigma_{2} \quad$ Geleidingsvermoë van dic grond

$\varepsilon_{2} \quad$ Permittiwiteit van dic grond

$\gamma \quad$ Voortplantingskonstante $=\sqrt{R G}$

\section{AGTERGROND}

Spoornet is deurlopend besig met dic evaluering en verbetering van sinjaalstelsels. Die doel hiervan is om die huidige roetes, met die verskillende samestellings van die treine, optimaal te kan benut, sonder om die veiligheid van bewegings te beïnvloed. Aangesien enige van hierdie stelsels altyd in die omgewing van die trekkragstelsel sal funksioneer, is dit noodsaaklik dat betroubare modelle beskikbaar sal wees om die elektromagnetiese versoenbaarheid van dic stelsels mec te voorspel en te evalueer. Hierdie noodsaaklikheid word verder aangehelp deur die vinnige vordering op dic gebied van drywingselektronika, en veral die toepassings hiervan in lokomotiewe. Hierdie ontwikkeling bring mee dat strome oor 'n wye frekwensicbereik in 
die trekkragstelsel voorkom, en die sinjalering kan beïnvloed.

Die spoorstroombaan (treindetcksie) is een van die primêre insette na die sinjaalstelsel en die betroubare werking hiervan is essensicel vir die veilige en doeltreffende beheer van verkeer. Modelle vir die bestudering van die spoorstroombaan en die bepaling van dic elektromagnetiese limicte waarbinne dit nog veilig kan funksioneer, is dus van kardinale belang.

\section{MODELLE VIR DIE SPOORSTROOMBAAN}

Twee tipes modelle word benodig by die bestudering en ontwerp van die spoorstroombaan, naamlik:

(a) Modelle vir die bestudering van die werking van die spoorstroombaan.

(b) Modelle vir dic bestudering van die invloed van steurings op die spoorstroombaan as gevolg van strome in die trekkragstelsel.

Vir die eerste geval, (a), word drie modelle vir die spoorstroombaan behandel. Dic cerste hicrvan is in terme van die klassicke transmissiclynmodel. Dit kan gebruik word om die verloop van die spanning en stroom op enige punt langs die lengte van die spoorbaan tc bepaal. Hierdic, en die ingangsimpedansie vir gegewe terminasies en lengte van die spoorstroombaan is maar enkele van die toepassings waarvoor dié model gebruik kan word.

Die tweede spoorstroombaanmodel is ' $n$ numeriese model in terme van transmissiematrikse wat vir die spoorbaan bepaal word. Hierdie model is veral geskik vir die berekening van die invloed van gekonsentrecrde stroombaanelemente op gegewe posisies van die spoorbaan.

Die laaste model vir die spoorstroombaan, soos in (a) genoem, is in terme van die sogenaamde 'T'- en 'Pl'-netwerke. Hierdie model is veral geskik wanneer die strome en spannings langs die lengte van die spoorstroombaan onbelangrik is en daar slegs in die strome en spannings by die ingang en uitgang van die spoorstroombaan belang gestel word.

'n Model waarmee die invloed van steurings op spoorstroombane bestudeer kan word, is nodig sodat elcktriese limiete vir die spesifieke spoorstroombaan onder beskouing, binne die clektromagneticse omgewing van die trekkragstelsel, bepaal kan word. 'n Model van hierdie aard is omvangryk en kan dus nie hier in detail bespreck word nie.

Enige van dić genoemde modelle het egter ' $n$ aantal gemeenskaplike insette nodig voordat dit van enige waarde kan wees. Die vernaamste hiervan is:

(a) Die elcktriese parameters van die spoorbaan.

(b) Die verandering van die parameters met frekwensie, spoorstroom en temperatuur.

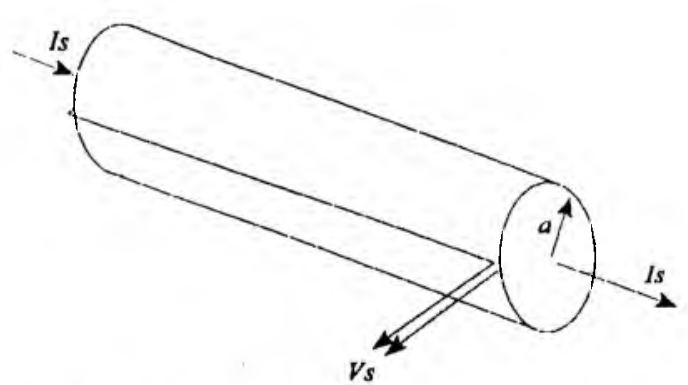

FIGUUR I: Meting van interne impedansie van 'n ronde geleier. (c) Dic impedansies van die stelsel van geleiers in die trekkragstelsel.

(d) Die verspreiding van die trekkragstroom tussen die stelsels van geleiers en die grond, as 'n lunksic van die alstand vanaf die substasic en ook die frek wensie betrokke (gelyken wisselstroom)

Voordat daar dus opsommend na die genoemde modelle teruggekeer work, sal die elektromagnetiese modetle vir die bogenoemde parameters in meer detail bespreek word.

\section{DIE SPOOR AS 'N RONDE GELEIER}

Vir die doel van treindeteksic kan die spoorbaan as 'n transmissielyn gemodelleer word. Die primêre konstantes van die spoorbaan R, L. G en C kom as verspreide elemente langs dic lengle van die spoorbaan voor. Die vorm van die spoor malk dit egter onmoontlik om analitiese uitdrukkings vir hierdie parameters te verkry.

Tans is uitgebreide programmatuurpakkette ook beskikbaar gebaseer op die metodes van eindige elemente. Hierdie numeriese metodes kan gebruik word om die impedansies te bereken, ${ }^{1.2}$ maar is nadelig omdat die insig wat met analitiese oplossings gepaardgaan, verlore gaan. Soos verder uit hierdic bydrac sal blyk, is dit ook nie nodig om vir redelike akkuraatheid hierna oor te gaan nie. Om hierdie rede is 'n metode in terme van interne en eksterne impedansies ontwikkel, waarvolgens die spoor met 'n ekwivalente ronde geleier vervang kan word, sonder om groot foute te maak. ${ }^{3} \mathrm{Met}$ die spoor as ronde geleier beskou, kan eenvoudige analitiese uitdrukkings vir die berekening van die genoemde parameters verkry word.

Indien die nabyheidseffek in die geval van ronde geleiers buite rekening gelaat word, kan die magnectveld as sirkulêr om die geleiers beskou word. Indien die impedansie van die ronde geleier gemeet word deur 'n bekende stroom daardcur te laat vloci, en die spanning oor 'n gegewe lengte op die oppervlakte daarvan te meet, kan die interne impedansie daarvan bepaal word (sien figuur 1). Omdat dic magneetveld sirkulêr om die geleier is en dieselide vloed altyd deur die spanningsmeetgeleiers ingesluit word, sal die gemete interne impedansie oral op die oppervlakte van die gelcier dieselfle wees.

Indien dieselfde meting op 'n spoor gedoen word, sal die meting, op verskillende posisies op die oppervlak verskillende resultate lewer, omdat die magnetiese vloed wat deur die spanningsmeetgeleiers ingesluit word, by elke punt verskil. Indien die spanningsmeetlus by 'n gegewe punt op Jic oppervlakte van die spoor vergroot word om meer van die vloed butte die spoor in te sluit, sal die gemete interne impedansie telkens vergroot (sien fïguur 2). Dit is juis hierdie eienskap wat gebruik word om die interne impedansie van die spoor in terme van ronde geleiers te definieer.

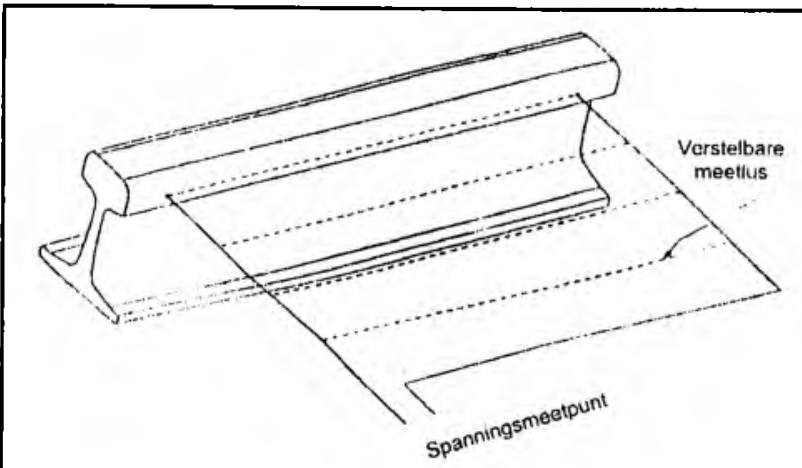

FIGUUR 2: Meting van spoorimpedansie met 'n verstelbare meetlus. 
Deur die impedansie van die spoor op verskeie punte op die oppervlak te meet en telkens die meetlus te vergroot, kan 'n konstante impedansiekontoer om die spoor verkry word wat nagenoeg sirkulêr is en nog aan die oppervlak van die spoor raak. Die impedansie van die punt waar die konstante impedansiekontoer die spoor raak, sal ook die punt van maksimum oppervlakte-impedansie van die spoor wees en word as die interne impedansie van die spoor geneem. Om die radius van die ekwivalente ronde geleier te vind, word daar soos volg te werk gegaan:

Die afstand tussen die snypunte van die impedansiekontoer met die hartlyn van die spoor (punte A en B in figuur 3) word gehalveer en as die middelpunt van die ekwivalente ronde spoor geneem. In figuur 3 word dit met 'n "O" gemerk. Die radius van die geleier word dan geneem vanaf hierdie middelpunt tot by die punt van maksimum impedansie, "C" in figuur 3 .

Uit eksperimentele metings op verskeie tipes spore, by 'n frekwensie van $50 \mathrm{~Hz}$, is gevind dat die omtrek van die ekwivalente ronde geleier en die van dic spoor nagenoeg dieselfde is.

\section{KONTROLERING VAN DIE EKWIVALENTE RONDE SPOOR}

Om die prosedure wat bo in paragraaf 3 gebruik is in die verkryging van 'n ekwivalente ronde geleier te kontroleer, is die betrokke impedansies van twee tipes modelspore gemeet. Die eerste het 'n vorm wat ooreenstem met dié van die werklike spoor, en die tweede is 'n ronde geleier met dieselfde omtrek as dié van die modelspoor. Beide die spore was van geelkoper en 3 meter lank.

Die kortsluitingangsimpedansies word in figure 4 en 5 getoon en toon goeie ooreenstemming binne die meetakkuraatheid van die opstelling wat gebruik is.

\section{IMPEDANSIE VAN DIE SPOOR}

Met 'n ekwivalente ronde geleier vir die spoor gevind, kan uitdrukkings vir die interne en eksterne impedansie van die spoor nou gevind word deur die toepassing van Maxwell se vergelykings vir ronde spore bokant 'n geleidende grondoppervlak.

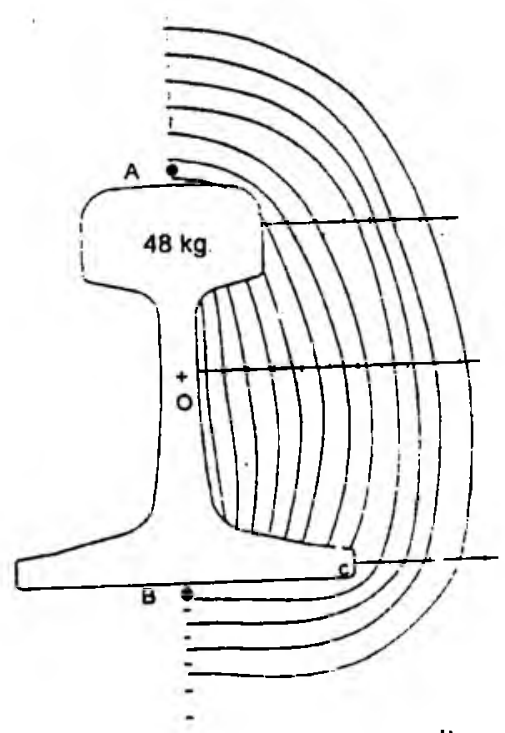

FIGUUR 3: Impedansiekontoere om die spoor

\subsection{Interne impedansie}

Die oplossings van Maxwell se vergelykings lewer 'n uitdrukking in terme van besselfunksies vir die interne impedansie van die spoor, ${ }^{4}$ naamlik:

$$
z_{1}=\frac{1}{\Pi \sigma_{1} a_{2}} \cdot f \frac{Y_{1} a}{2}\left[\frac{J_{0}\left(J Y_{1} a\right)}{J_{1}\left(J Y_{1} a\right)}\right]
$$

$\operatorname{met} Y_{1}-\sqrt{f \omega \mu_{1} \sigma_{1}-\omega^{2} e_{1} \mu_{1}}$

By hoë frekwensies (waar $\gamma_{1} a>2.5$ ) kan vergelyking ( 1 ) benader word deur die volgende uitdrukking: ${ }^{4}$

$$
z_{\Lambda}=\frac{\sqrt{2 \omega \mu_{1} \sigma_{1}}}{4 \Pi \sigma_{1} a}+j \omega\left[\frac{\sqrt{2 \mu_{2} \sigma_{1} / \omega}}{4 \pi \sigma_{1} a}\right]
$$

In vergelyking (2) verteenwoordig die reële gedeelte die weerstand van die spoor en die imaginêre geleelte die reaktansic. By lae frekwensies word die weerstand en die induktansie van die spoor onderskeidelik gegee deur:

$$
\begin{aligned}
& R_{1}=\frac{1}{\sigma_{1} \pi a^{2}} \\
& L_{1}=\frac{\mu_{1}}{8 \pi}
\end{aligned}
$$
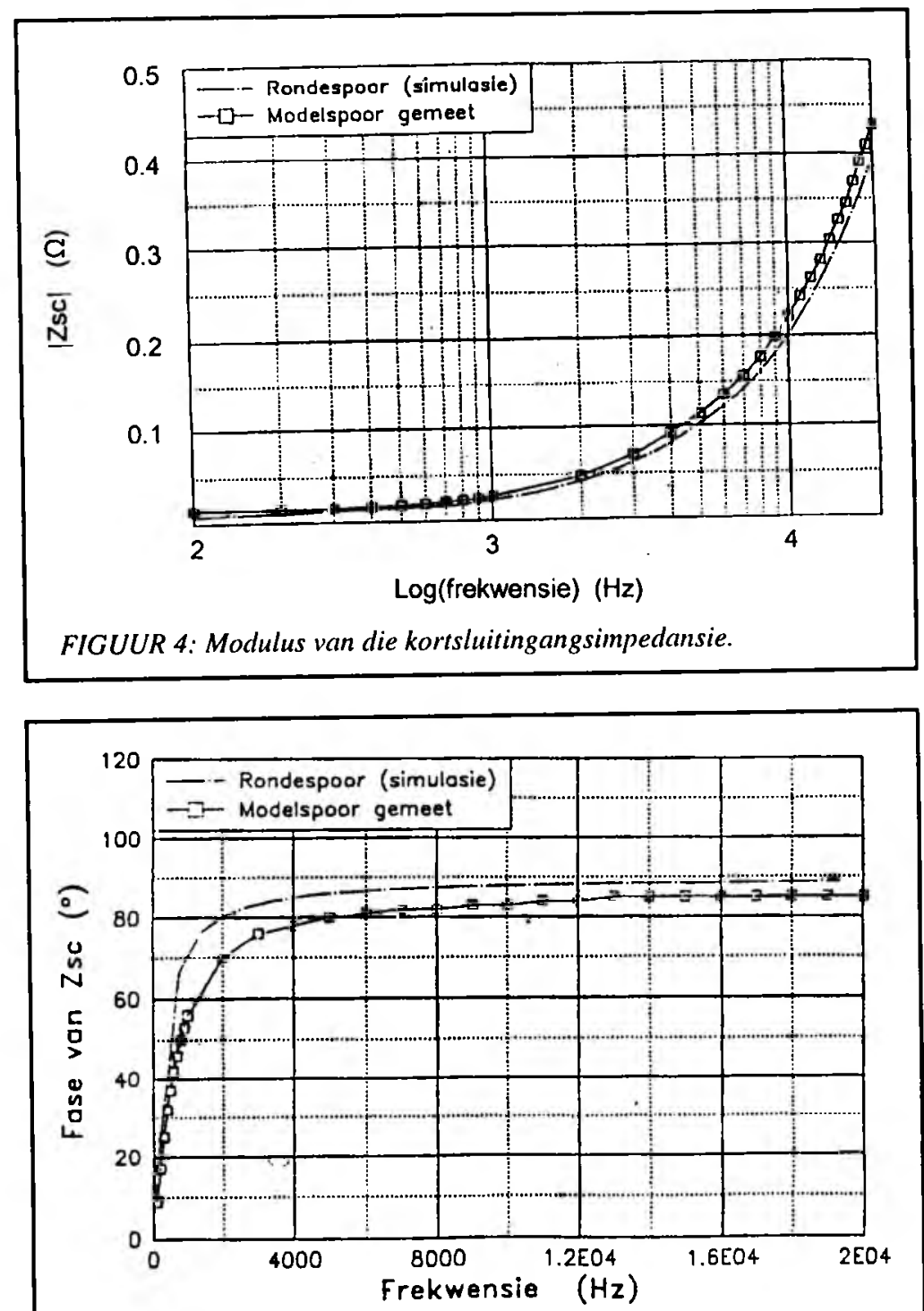

FIGUUR 5: Fase van die kortsluitingangsimpedansie. 


\subsubsection{Meting van die interne impedansie}

Volgens die prosedure waarmee die ekwivalente ronde geleier bepaal word, word die interne impedansie van die spoor gelykgestel aan die maksimum oppervlakimpedansie van die spoor. Met die geleidingsvermoë van die spoor bekend, kan die permeabiliteit van die spoor dus bepaal word. Die resultate van hierdie metings, vir 'n UIC-A tipe spoor, word in figuur 6 getoon.

Uit figuur 6 is dit duidelik dat die impedansie van die spoor verander met spoorstroom. Dit is omrede die spoor magneties is en deur die stroom gemagnetiseer word. ${ }^{6}$ Die permeabiliteit, en die verandering daarvan met spoorstroom is volgens vergelyking (2) bereken en word in figuur 7 getoon.

\subsection{Eksterne impedansie van die spoor}

Die eksterne impedansie van die spoor ontstaan as gevolg van die magnetiese vloed buite die geleier en word nie deur die materiaal van die spoor, soos in die geval van die interne impedansie, beïnvloed nie. Dit is slegs 'n funksie van die geometrie van die spore en die eienskappe van die grond. By die frekwensies en spoorstroombaanlengtes waarby normaalweg gewerk word, bestaan die eksterne impedansie slegs uit die eksterne induktansie, en word deur vergelyking (5) gegee. ${ }^{4}$

$$
L_{\text {. }}-\frac{\mu_{2}}{2 \pi} \ln \left(\frac{2 b}{a}\right)
$$

\subsection{Admittansie van die spoorbaan}

Die admittansie tussen die spore bestaan uit die konduktansie en kapasitansie tussen die spore. By die frekwensies wat normaalweg vir die spoorstroombane gebruik word, is die kapasitansie gewoonlik weglaatbaar en die konduktansie die oorheersende faktor. Die uitdrukkings hiervoor word ook verkry deur die oplossing van Maxwell se vergelykings ${ }^{4}$ en word hieronder weergegee.

$$
\begin{aligned}
& G=\frac{\pi \sigma_{2}}{\ln \left(\frac{2 b}{a}\right)} \\
& c=\frac{\pi \sigma_{2}}{\ln \left(\frac{2 b}{a}\right)}
\end{aligned}
$$

\subsection{Kontrolering van die modelle vir die impedansies van die spoorbaan}

Die geldigheid van die modelle vir die impedansies van die spoorbaan is gekontroleer deur eksperimentele metings op 'n toetstrajek uit te voer. Die kortsluit- en opebaan-ingangsimpedansie van die spoor is by verskillende frekwensies gemeet, waarna die parameters $R, L$, $G$ en $C$ bereken is deur gebruik te maak van die volgende transmissielynvergelykings: ${ }^{7,13}$

$$
\begin{aligned}
& z_{0} \cdot \sqrt{z_{o c} \cdot z_{s c}} \\
& \operatorname{tanhY} 1 \cdot \sqrt{\frac{z_{a c}}{z_{o c}}} \\
& z_{0}=\sqrt{\frac{R+J \omega L}{G+J \omega C}}
\end{aligned}
$$
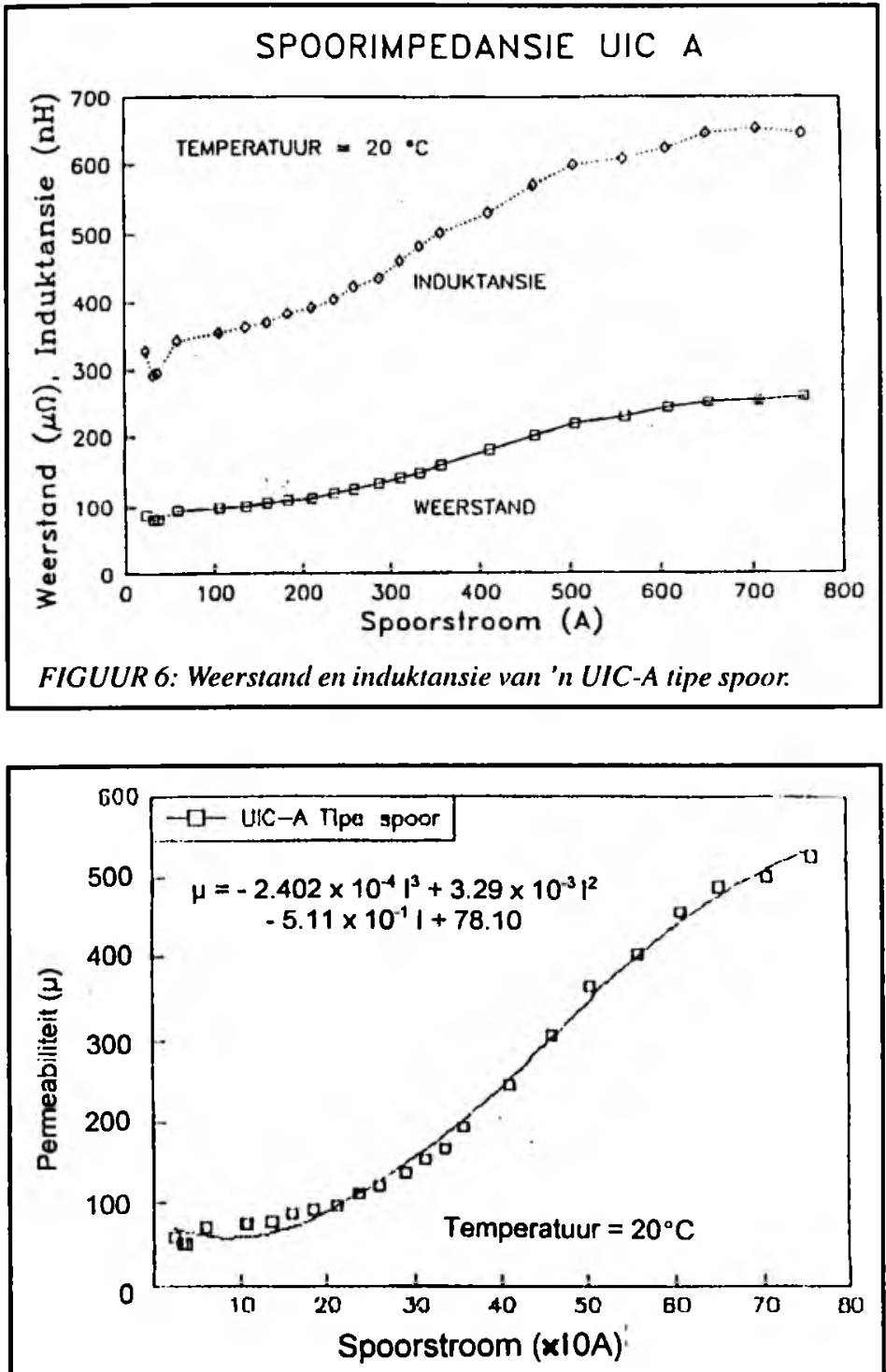

FIGUUR 7: Stroomafhanklikheid van die permeabiliteit.

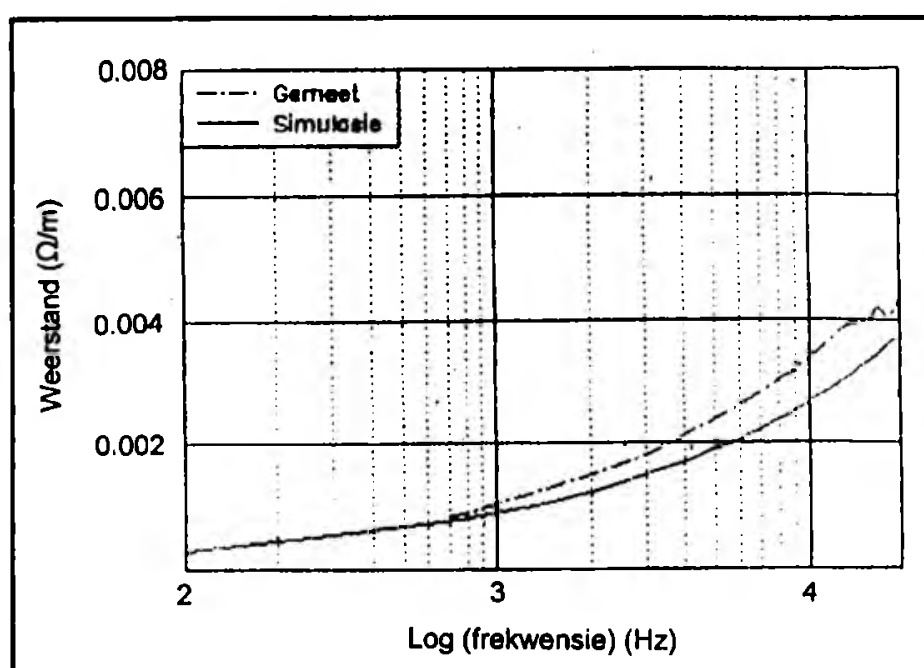

FIGUUR 8: Gemete en berekende weerstand van 'n spoorbaan.

$Y \cdot \sqrt{(R+j \omega L) \cdot(G+j \omega C)}$

Die weerstand en die induktansie van die spoor is met behulp van die modelle bereken en word in figuur 8 en 9 saam met die gemete resultate op dieselfde assestelsel voorgestel. Die verskil in induktansic in figuur 9 


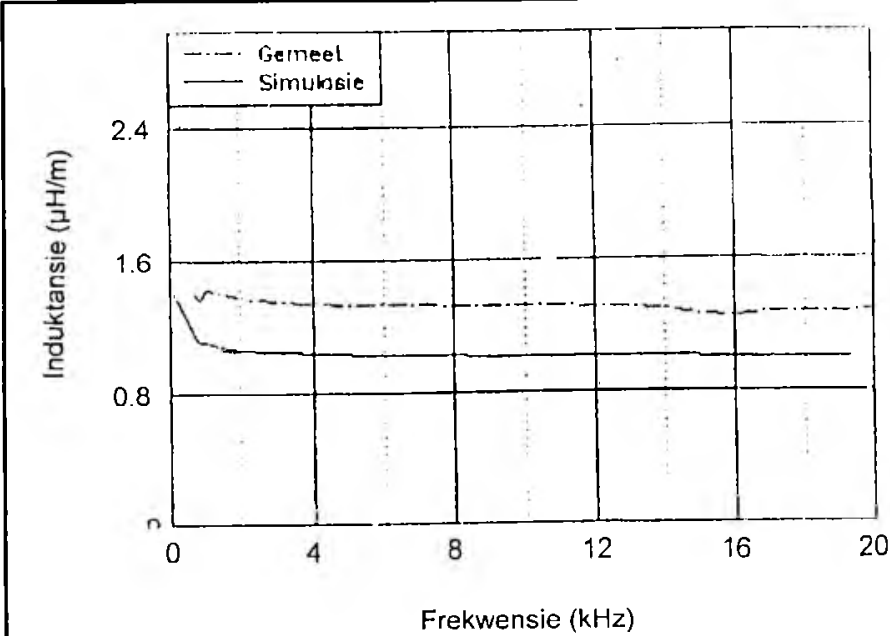

FIGUUR 9: Gemete en berekende indaktansie van 'n spoorbaan.

word veroorsaak deurdat dic relaticwe permeabiliteit van die grond groter is as een vir die meetlrajek. Die berekende waarde is gedoen deur aan te neem dat die relatiewe permeabiliteit van die grond $\mu_{r}=1$ is. Indien die permeabiliteit van die grond $\left(\mu_{2}\right.$ in vergelyking $\left.(5)\right)$ aangepas word om 'n groter relatiewe permeabiliteit te hê, sal dic berekende en gemete induktansic baic beter ooreenstem.

\section{MODEILERING VAN DIE IMPEDANSIES IN DIE TREKKRAGSTELSEI}

Die impedansies van die stelsel van geleiers in die trekkragstelsel word benodig vir die berekening van die verspreiding van trekkragstrome. In die wisselstroomgeval speel die interne, eksterne en wedersydse impedansies' 'n groot rol. In die model vir die berekening hiervan word die geleiers (spore
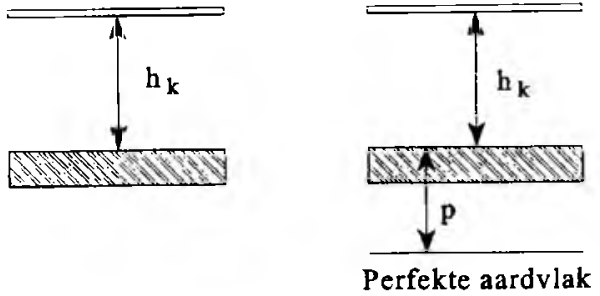

FIGUUR 10: Definiëring van 'n perfekle aardviak.
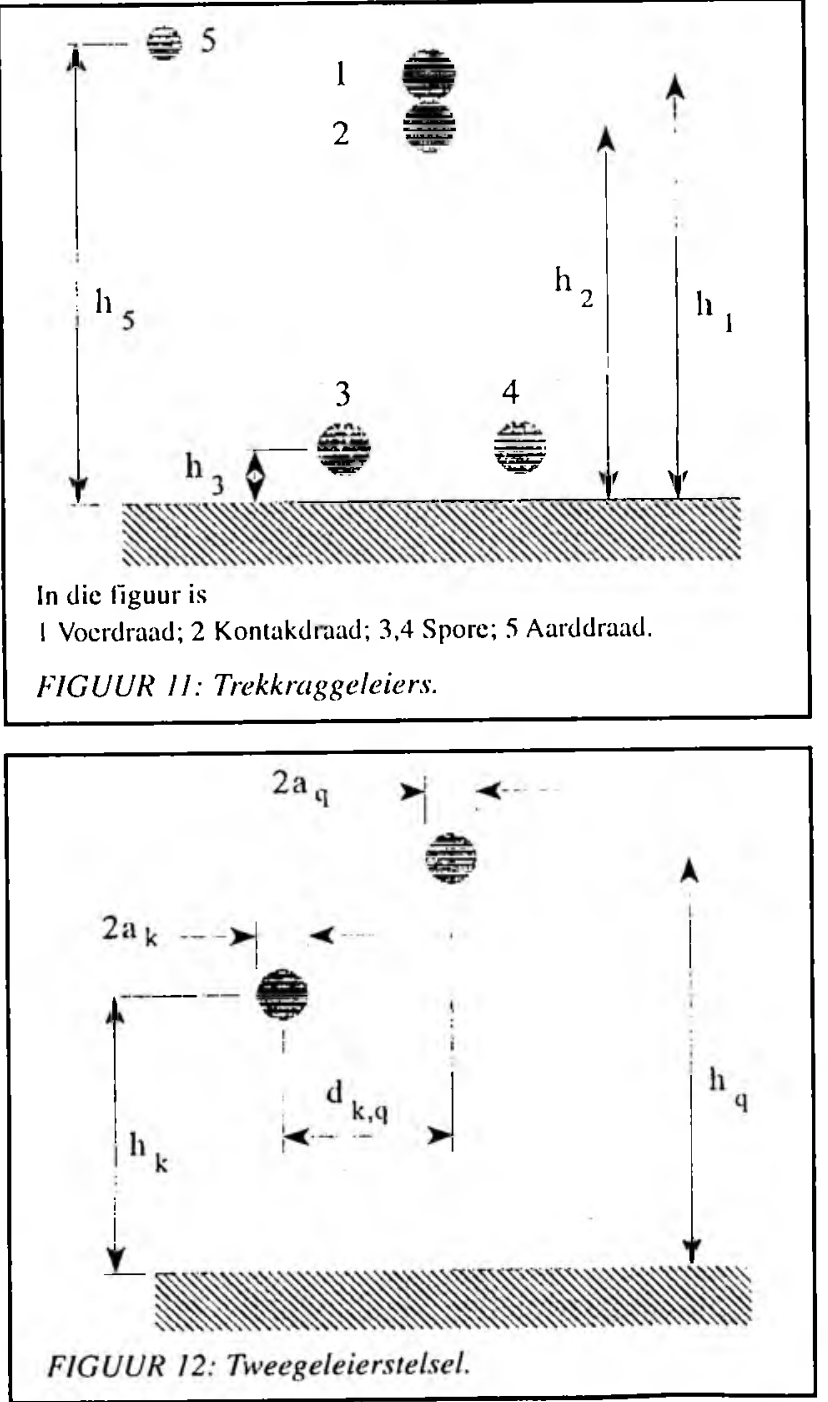

ingesluit) van die trekkragstelsel elk as 'n stroombaan met ' $n$ aard-trugeleier beskou. Verder word die konsep van 'n ideale aardvlak op 'n komplekse diepte p onder die grond ingevoer ${ }^{8}$ (sien figuur 10 ).

Die gebruik van 'n komplekse diepte is nodig sodat die eksterne impedansie van die geleier ook die grondweerstandkomponent van die genoemde stroombane in berekening kan bring. Figuur 11 toon die relaticwe posisies van die betrokke geleiers.

Beskou die $k_{d k}$ en $\mathrm{q}_{\mathrm{dk}}$ geleier van die stelsel soos aangedui in figuur 12. Omdat die twee geleiers elk, tesame met die aardvlak, 'n geslote lus vorm, is daar self-sowel as wedersydse induktansies betrokke.

Die selfimpedansic en wedersydse impedansie van die twee geleiers word bereken deur die volgende twee vergelykings:

$$
\begin{aligned}
& z_{s}=\frac{j \omega \mu_{0}}{2 \pi} \ln \left[\frac{2(h+p)}{a_{k}}\right] \\
& z_{m}=\frac{j \omega \mu_{0}}{2 \Pi} \ln \left[\frac{\sqrt{\left(h_{q}+h_{k}+2 p\right)^{2}+d^{2} k q}}{\sqrt{\left(h_{q}-h_{k}\right)^{2}+d^{2}{ }^{2}}}\right]
\end{aligned}
$$

\section{TREKKRAGSTROOMVERSPREIDING}

Die verspreiding van trekkragstrome word weens twee redes benodig, naamlik

(a) vir die berekening van dic interne impedansies van die spoor, aangesien dit 'n lunksie van die spoorstroom is;

(b) vir die berekening van die steurings op spoorstroombane.

Afsonderlike modelle vir gelyk- en wisselstroomverspreiding is ontwikkel. Dic gelykstroom-model is geldig oor die totale afstand tussen die lokomoticf en dic substasie. In die wisselstroomgeval is twee modelle van toepassing. Die eerste is geldig oor ' $n$ voorafhepaalde afstand vanaf dic lokomolief en substasic terwyl die tweede vir dic oorblywende gedeelte van die trajek geld. Vir die toepassing in spoorstroombane is die laasgenoemde wisselstroommodel in die meeste gevalle voldoende.

\subsection{Gelykstroommodel}

In dic gelykstroomgeval word die spoor in terme van dic weerstand per eenheidslengte en 'n konduktansie na die aardvlak 

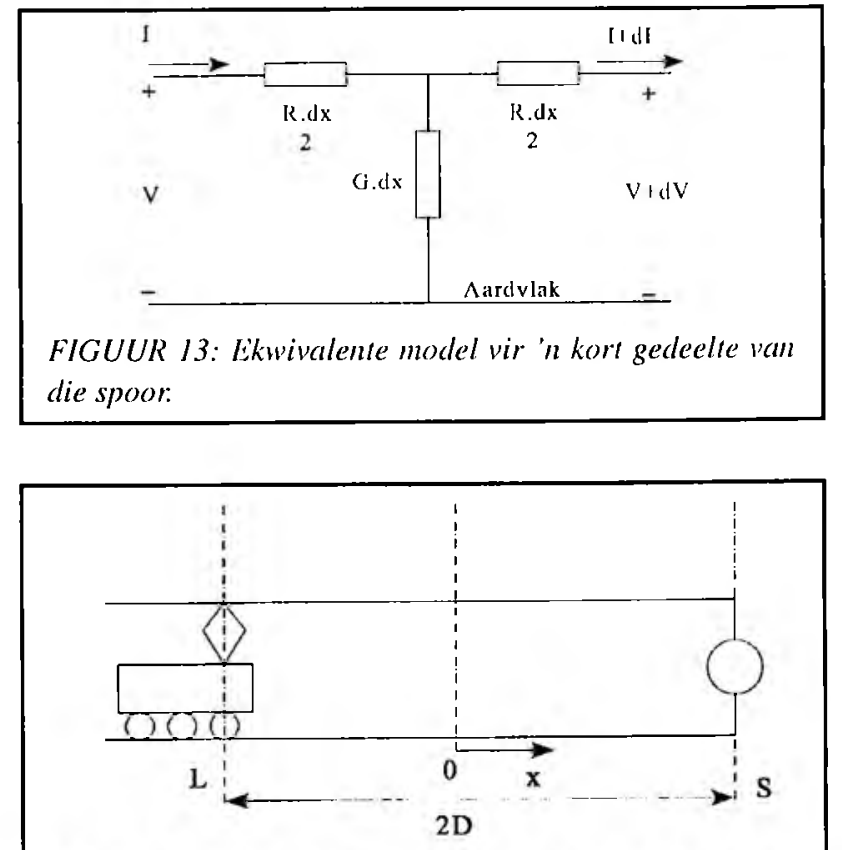

FIGUUR 14: Posisie van die substasie en die lokomotief.
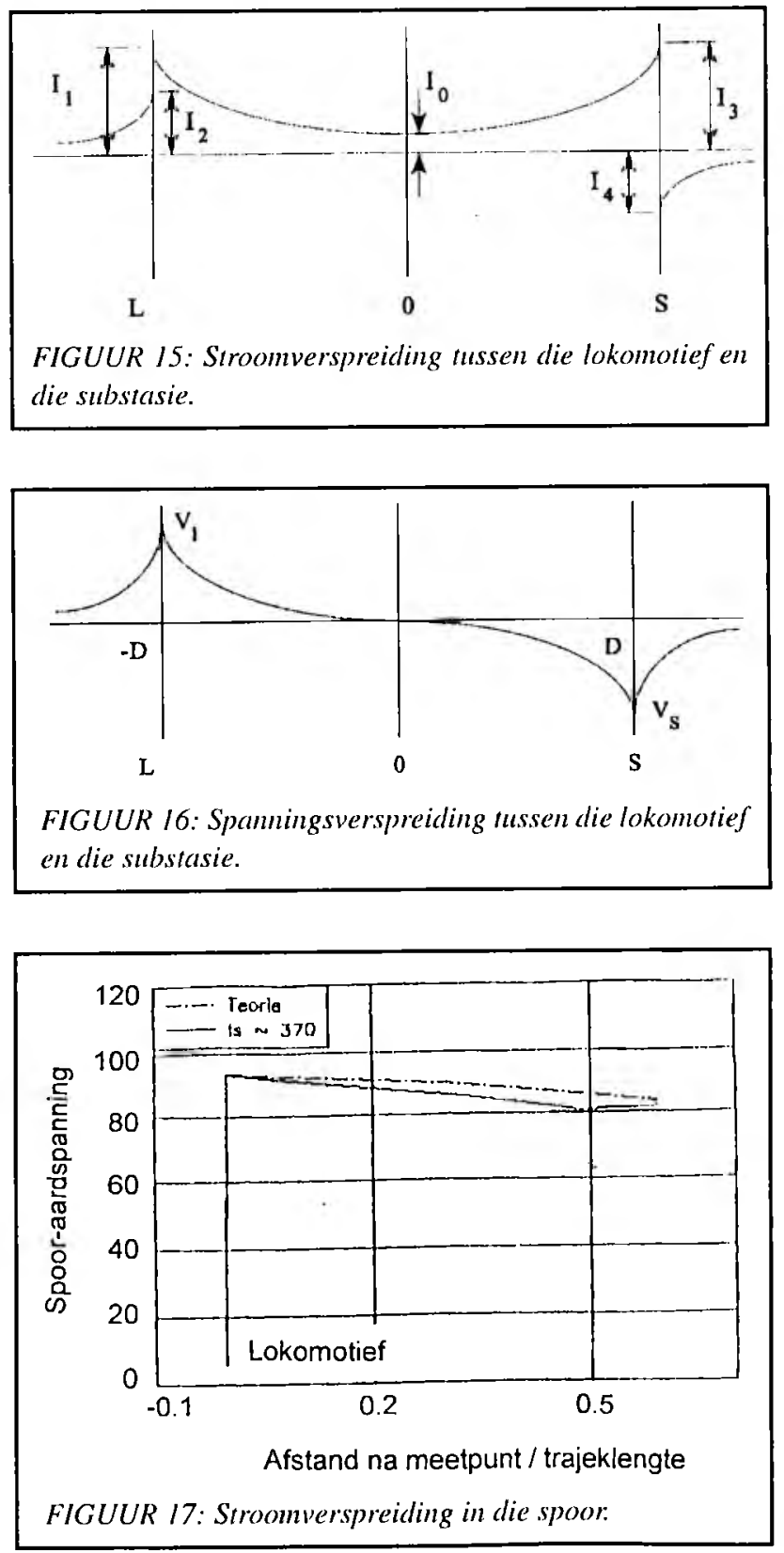

gemodelleer. Dil word in figuur 13 getoon. Die posisies van die lokomoticf en die substasic word in figuur 14 getoon.

Deur differensiaal vergelykings hiervoor op te stel en alan die hand van die randvoorwardes op te los, word dic volgende vergelykings vir die strome en spannings verkry: ${ }^{4,11}$

(a) Stroom- en spanningverspreiding tussen die substasic en dic lokomoticl.

$$
\begin{aligned}
& I(x)=\frac{I_{1}}{\cosh Y D+\sinh Y D} \cosh Y x \\
& V(x)=\frac{I_{1} z_{0}}{\cosh Y D+\sinh Y D} \sinh Y x
\end{aligned}
$$

(b) Stroom en spanning aan weerskante van dic lokomoticl en substasic.

$$
\begin{aligned}
I(x) & =\frac{I_{1} \sinh \gamma D}{\cosh Y D+\sinh Y D} e^{Y[x D)} \\
& =\frac{I_{1}}{\operatorname{coth} \gamma D+1} e^{-\gamma(x-D)} \\
V(x) & =\frac{I_{1} z_{0} \sinh \gamma D}{\cosh Y D+\sinh Y D} e^{-\gamma(x-D)} \\
& =\frac{I_{1} z_{0}}{\operatorname{coth} Y D+1} e^{-\gamma(x-D)}
\end{aligned}
$$

Hierdie vergelykings word in figuur 15 en 16 voorgeslel.

Die gelykstroommodelle is met eksperimentele metings gekontroleer en toon gocic ooreenstemming, binne die meetakkuraatheid van veranderlikes soos grondgeleidingsvermoë en stroom. Die teoretiese en gemete resultate van die stroom in die spoor word in liguur 17 getoon.

\subsection{Stroomverspreiding vir wisselstroom}

\subsubsection{Stelselimpedansies}

Beskou die geleiers van figuur 11 hierbo, maar in dic lengle voorgestel, soos in figuur 18 getoon word.

Dic spannings $\mathrm{V} 1$.. $\mathrm{V} 5$ is dic spannings wat tussen dic aarde en dic onderskeic geleiers ontstaan. $\mathrm{V} 3 \mathrm{en} \mathrm{V4}$ is byvoorbeeld dic spoor-aardspannings by dic ingang van die trajek onder beskouing. So ook is $\mathrm{V}^{\prime}$ en $\mathrm{V} 4$ ' dic spoor-aardspannings aan die cinde van dic trajek. Aan dic hand van figuur $18 \mathrm{kan}$ dic spannings aan die ingang van dic trajek in terme van die stroom, impedansics en die spanning aan die cinde van die trajek geskryf word as: "

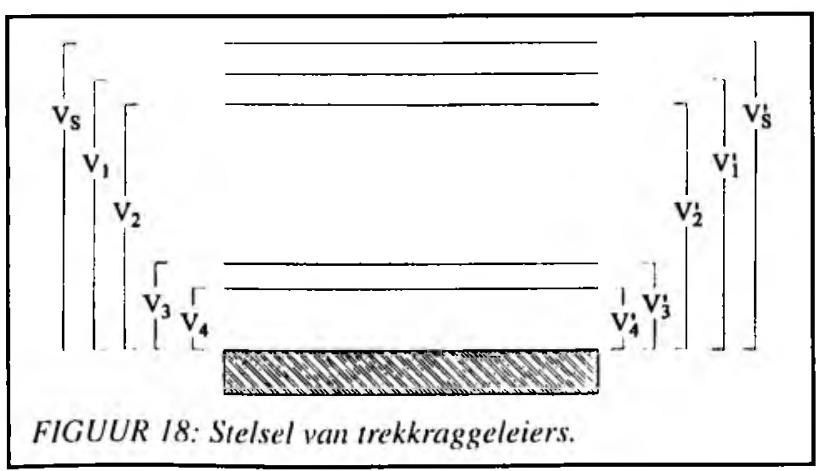




$$
\left[\begin{array}{c}
V_{1} \\
V_{2} \\
V_{3} \\
V_{1} \\
V_{5}
\end{array}\right]=\left[\begin{array}{lllll}
z_{11} & z_{12} & z_{13} & z_{14} & z_{15} \\
z_{21} & z_{22} & z_{23} & z_{24} & z_{25} \\
z_{31} & z_{32} & z_{33} & z_{34} & z_{35} \\
z_{41} & z_{12} & z_{43} & z_{44} & z_{45} \\
z_{51} & z_{52} & z_{53} & z_{54} & z_{55}
\end{array}\right]\left[\begin{array}{c}
I_{1} \\
I_{2} \\
I_{3} \\
I_{1} \\
I_{5}
\end{array}\right]+\left[\begin{array}{c}
V_{1}^{\prime} \\
V_{2}^{\prime} \\
V_{3}^{\prime} \\
V_{4}^{\prime} \\
V_{5}^{\prime}
\end{array}\right]
$$

In vergelyking 18 is

$$
z_{k q} \cdot z_{1}+\frac{j \omega \mu_{0}}{2 \pi} \ln \left[\frac{2(h+p)}{a_{k}}\right] \text { vir } k-q
$$

en

$$
z_{m}=\frac{j \omega \mu_{0}}{2 \pi} \ln \left[\frac{\sqrt{\left(h_{q}+h_{k}+2 p\right)^{2}+d_{k q}^{2}}}{\sqrt{\left(h_{q}-h_{k}\right)^{2}+d_{k q}^{2}}}\right] v 1 I k+q
$$

met $\mathrm{a}_{\mathrm{k}}$ die radius van die $k$ de geleier en $\mathrm{Z}_{\mathbf{i}}$ die interne impedansie daarvan.

Vir die berekening van die stroomverspreiding is dit nodig om te weet of die trustroom net in een of albei die spore vloei. Hier word die volgende aannames gemaak om die oplos van vergelyking (18) moontlik te maak: ${ }^{12}$

(a) Die spoor wat vir trugeleiding gebruik word, is deurgaans aan die grond verbind, en geen spanning bestaan dus tussen die spoor en die aardvlak nie.

(b) Die geïsoleerde spoor is heeltemal van die aarde geïsoleer.

\subsection{Berekening van die stroomverspreiding}

Om die stroom te verkry, moet die inverse van die impedansiematriks in vergelyking (18) bereken word, en deur verder die betrokke randvoorwaardes toe te pas volg dat: "

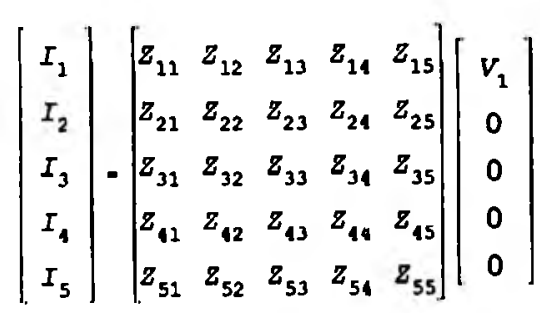

Die totale stroom wat in die bobaan vloei, word gegee deur $\mathrm{I} 1+12$ en dus kan die gedeelte van die stroom wat in die voerdraad vloei, bepaal word, naamlik:

$$
\frac{I_{1}}{I_{1}+I_{2}} \cdot \frac{Y_{11}}{Y_{11}+Y_{21}}
$$

Netso kan die stroom wat in die ander geleiers vloei, bepaal word deur:

$$
\frac{I_{k}}{I_{1}+I_{2}} \cdot \frac{Y_{k 1}}{Y_{11}+Y_{21}}
$$

Die gedeelte van die stroom wat in die grond vloei, kan ook bereken word, aangesien dit die verskil tussen die totale bobaanstroom en die som van die strome in die spore en die aardgeleier, is. Dus volg dat

$$
\begin{aligned}
I_{\sigma} & =I_{1}+I_{2}-\left(I_{3}+I_{1}+I_{5}\right) \\
& =Y_{11}+Y_{21}-\left(Y_{31}+Y_{41}+Y_{51}\right) V_{1}
\end{aligned}
$$

Hieruit volg nou dat die gedeelte van die totale stroom wat deur die aarde terugvloei, gegee word deur:

$$
\frac{I_{g}}{I_{1}+I_{2}} \cdot \frac{Y_{11}+Y_{21}-\left(Y_{31}+Y_{11}+Y_{51}\right) V_{1}}{Y_{21}+Y_{12}}
$$

\section{MODELLE VIR DIE SPOORSTROOMBAAN}

Modelle vir die nodige insette vir die spoorstroombaanmodelle is nou afgelei en daar kan nou voortgegaan word om die verskillende spoorstroombaanmodelle te beskou.

\subsection{Transmissielynmodel}

Soos voorheen genoem, kan die spoorbaan as ' $n$ transmissielyn beskou word. ' $n$ Lengte $\mathrm{dx}$ van die spoorbaan word in figuur 19 voorgestel. Die vergelykings van toepassing op die model word ook gegee. ${ }^{10}$

Karakteristieke impedansie

$$
z_{0}=\sqrt{\frac{R+J \omega L}{G+J \omega C}}
$$

Voortplantingskonstante

$$
Y \cdot \sqrt{(R+J \omega L) \cdot(G+J \omega C)}
$$

Ingangsimpedansie

$$
z_{1}-z_{0} \frac{z_{z} \cosh Y 1+z_{0} \sinh Y 1}{z_{0} \cosh Y 1+z_{r} \sinh Y I}
$$

Spanning en stroom as 'n funksie van die afstand vanaf die bron.

$$
\begin{aligned}
& V(x)=V_{0} \cosh Y x-I_{s} Z_{0} \sinh Y x \\
& I(x)=I_{s} \cosh Y x-\frac{V_{0}}{Z_{0}} \sinh Y x
\end{aligned}
$$

\subsection{Numeriese model met behulp van transmissiematrikse}

Die spoorbaan kan ook voorgestel word as 'n aantal vierklemnetwerke in kaskade gekoppel, soos in figuur 20 getoon word.

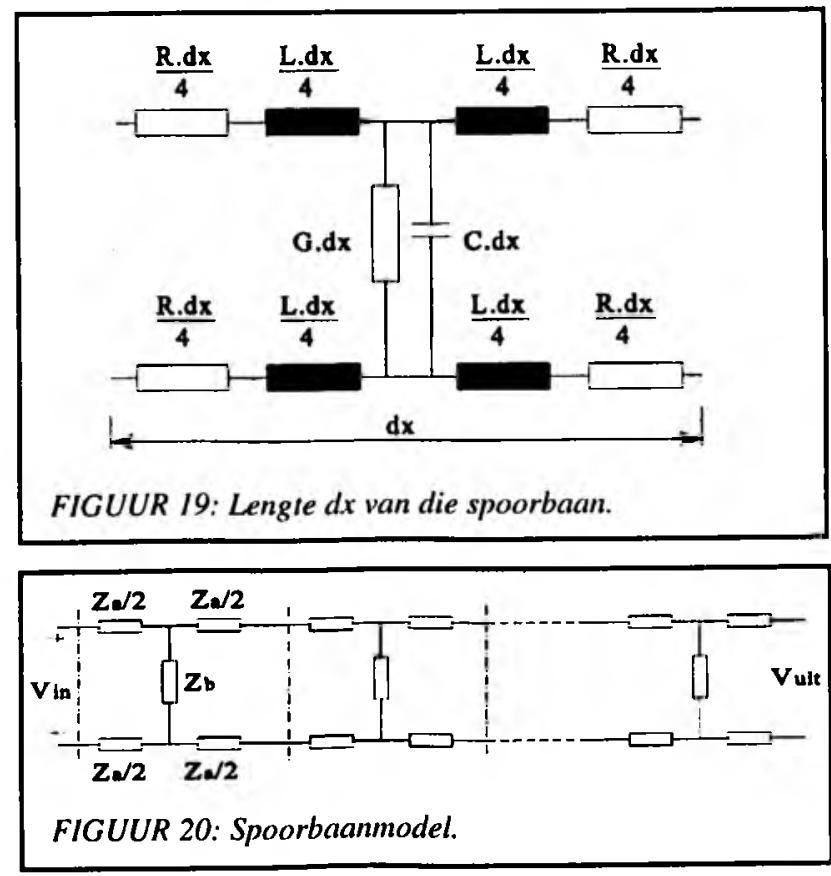


Die ingangspanning en ingangstroom kan in terme van enige aantal van die vierklemnetwerke en die uitgangspanning en stroom van die laaste netwerk geskryf word, naamlik:

$$
\left[\begin{array}{c}
V_{1 n} \\
I_{1 n}
\end{array}\right]-\left[\begin{array}{cc}
A_{1} & B_{1} \\
C_{1} & D_{1}
\end{array}\right] \cdot\left[\begin{array}{cc}
A_{2} & B_{2} \\
C_{2} & D_{2}
\end{array}\right] \cdots\left[\begin{array}{cc}
A_{n} & B_{n} \\
C_{n} & D_{n}
\end{array}\right] \cdot\left[\begin{array}{l}
V_{u 1 t} \\
I_{u 1 t}
\end{array}\right](31)
$$

Die elemente $\mathrm{A}, \mathrm{B}, \mathrm{C}$ en $\mathrm{D}$ word in terme van die primêre transmissielynkonstantes bereken volgens die volgende uitdrukkings, $P$ die lengte van die vierklemnetwerk.

$$
\begin{aligned}
& A=D=\left[\begin{array}{ll}
\frac{1}{2} & \left(R G-\omega^{2} L C\right) P^{2}+1
\end{array}\right]+y \\
& {\left[\frac{1}{2} \omega(R C+G) P^{2}\right]} \\
& B=R P+\frac{1}{2}\left[\frac{R^{2} G}{2}-\omega^{2} L\left(\frac{L G}{2}+R C\right)\right] P^{3}+J \omega \\
& {\left[L P+\frac{1}{2}\left(R L G+\frac{R^{2} C}{2}-\omega^{2} \frac{L^{2} C}{2}\right) P^{3}\right]} \\
& c \cdot G P+\jmath \omega C P
\end{aligned}
$$

Indien enige gekonsentreerde element op 'n gegewe posisie oor die spoorbaan gekoppel word, word 'n transmissiematriks daarvoor opgestel en by die betrokke matriks gevocg. Sodoende word die effek van dié element ook in ag geneem.

Beskou as 'n voorbeeld hiervan ' $n$ kapasitor wat by die uitgangsklemme van die $k_{\text {tak }}$ vierklemnetwerk gekoppel word, soos in figuur 21 getoon. Die transmissiematriks vir hierdie netwerk word dan herskryf deur die invloed van die kapasitor in ag te neem.

Vanuit figuur 21 kan die transmissiematriks $T_{\text {, vir die }}$ kapasitor neergeskryf word as

$$
T_{c}=\left[\begin{array}{cc}
1 & 0 \\
\frac{1}{z_{\sigma}} & 1
\end{array}\right]
$$

en die matriks vir die $k_{c k}$ vierklemnetwerk word dan gegee deur die produk van die transmissiematriks van die $k_{d c}$ element en die van die kapasitor.

$$
T_{k}=\left[\begin{array}{cc}
A & B \\
C & D
\end{array}\right] \cdot\left[\begin{array}{cc}
1 & 0 \\
j \omega C & 1
\end{array}\right]
$$

of

$$
T_{k}=\left[\begin{array}{lll}
A+\left(j \omega C_{k}\right) \cdot B & B \\
B+\left(j \omega C_{k}\right) \cdot D & D
\end{array}\right]
$$

\subsection{Ekwivalente netwerk vir die spoor- stroombaan}

Indien daar slegs in die strome by die in- of uitgang van die spoorstroombaan belang gestel word, kan die spoorstroombaan vervang word met 'n ekwivalente "T"- of "Pl"netwerk. Die impedansies van die netwerktakke kan dan in terme van die primêre transmissielynkonstantes bereken word soos in figuur 22 getoon is.

\subsection{Spoorstroombaansteuringsmodel}

Om 'n meer toepaslike model te verkry, word die geval van 'n dubbellyn beskou. Dic model is net so toepasbaar vir die enkellyngeval aangesien die aantal geleiers onder beskouing net minder word. Die geleiers in die trekkragstelsel van 'n dubbellyn word in figuur 23 getoon.

In die figuur is :

\section{1,3 die voerdrade; 2,4 die kontakdrade; $5 . .8$ die spore.}

Die verspreiding van die trekkragstrome word in die model as bekend beskou en word bereken soos hierbo in paragraaf 7 genoem is.

Om die steurings op die spoorstroombaan te bereken, word die spore elk beskou as ' $n$ afsonderlike stroombaan met ' $n$ aardtrugeleier. Die dubbellyn kan na 'n enkellyn gereduseer word deur die effek van die ander geleiers as spannings, wat in die spoor geïnduseer word, te modelleer. Die differensiaalvergelykings vir die oorblywende twee spore kan dan opgestel en aan die hand van gegewe randvoorwaardes opgelos word.

Die genoemde spannings word in die twee spore geïnduseer as gevolg van die strome in die bobaan, sowel as gevolg van die strome in die spore van die ander lyn. Hierdie spannings moet vooraf bepaal word.

Aan die hand van die voorafgaande word die elektriese model, in figuur 24, vir die oorblywende spore verkry.

Aan die hand van die voorafgaande figuur kan die differensiaalvergelykings vir die spore 1 en 2 neergeskryf word. ${ }^{12}$

Spoor nommer 1:

$$
T_{k}=\left[\begin{array}{cc}
A & B \\
C & D
\end{array}\right] \cdot\left[\begin{array}{cc}
1 & 0 \\
j \omega C & 1
\end{array}\right]
$$

$$
\frac{d I_{1}}{d x}-Y_{1} I_{1}
$$

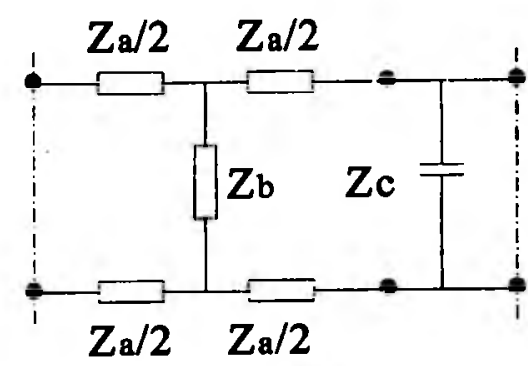

FIGUUR 2I: Kapasitor by die $k_{\text {de }}$ vierklemnetwerk. 
Spoor nommer 2:

$$
\begin{aligned}
& \frac{d V_{1}}{d x}-Z_{s 2} I_{2}+z_{21} I_{1}+V_{t 2} \\
& \frac{d I_{2}}{d x}-Y_{2} I_{2}
\end{aligned}
$$
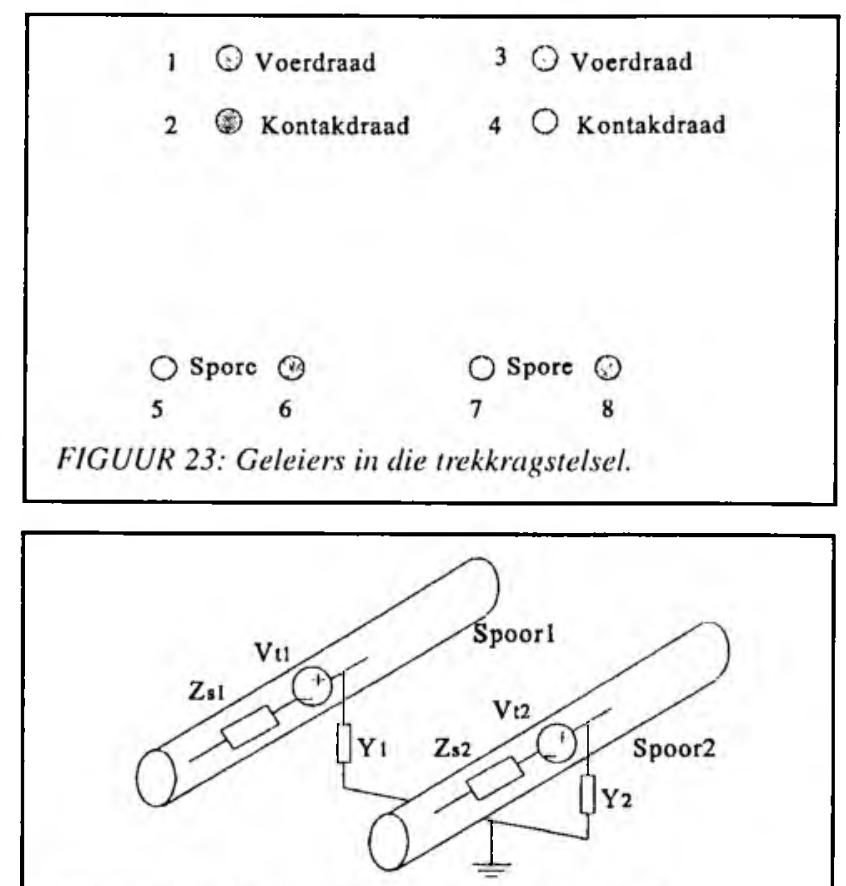

FIGUUR 24: Spoorstroombaansteuringsmodel.
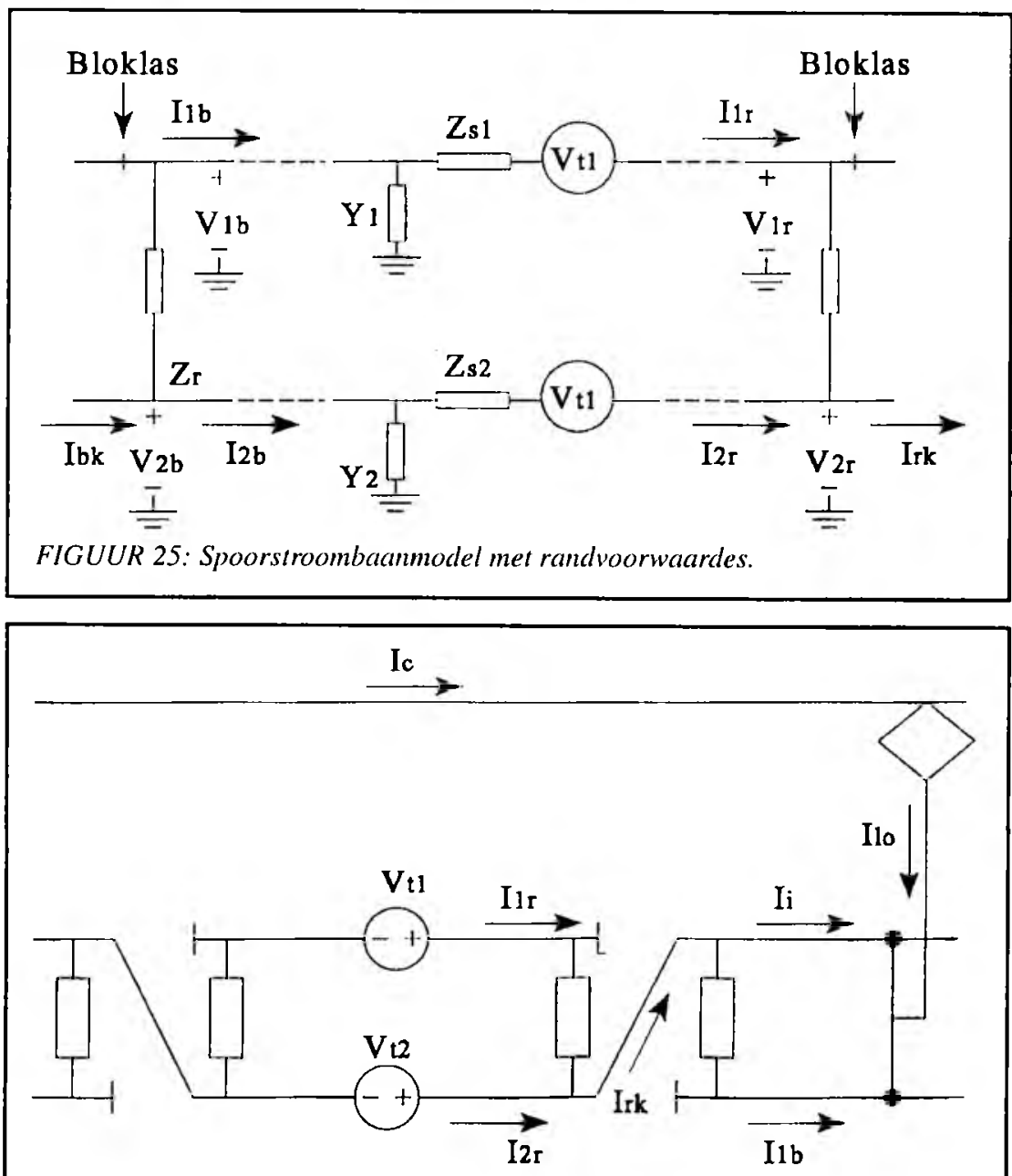

FIGUUR 26: Strome aan die einde van die spoorstroombaan.
Om die stel differensiaalvergelykings op te los, moet dic randvoorwaardes vir gegewe omstandighede eers bepaal word.

\subsubsection{Randvoorwaardes}

By dic bepaling van die randvoorwaardes word twee aannames ten opsigte van die spoor gemaak, ${ }^{12}$ naamlik:

(1) Die spoor wat vir trugeleiding gebruik word, is volledig geaard.

(2) Die geïsoleerde spoor is volledig geisoleer.

Twee gevalle van trugeleiding kan in die praktyk voorkom, naamlik die trugeleiding kan deur middel van een of albei die spore geskied. Figuur 25 toon die verbindings van 'n spoorstroombaan in die geval waar net een van die spore vir trugeleiding gebruik word.

Vanaf die figuur kan die volgende verbande vir die stroom en die spanning by die bron en ontvanger necrgeskryf word.

Vir die bron:

$$
\begin{gathered}
V_{1 b}+Z_{b}=I_{1 b}-V_{2 b}=0 \\
I_{1 b}+I_{2 b}=I_{b k}
\end{gathered}
$$

en by dic ontvanger is

$$
\begin{gathered}
V_{1 r}-Z_{r}=I_{1 r}-V_{2 r}=0 \\
I_{1 r}+I_{2 r}=I_{r k}
\end{gathered}
$$

Vergelykings (42) tot (45) is die algemene randvoorwaardes, by die bron en die ontvanger van die spoorstroombaan. Dit word verder beïnvloed deur die posisie van die lokomotief en 'n spesifieke geval word beskou.

\subsubsection{Lokomoticf buite die spoorstroom- baan, aan die ontvangkant van die spoorstroombaan}

Beskou die geval waar die lokomotief die aangrensende scksie beset. Hierdie situasie word in figuur 26 aangetoon.

Beskou die voorwaardes by die ontvanger van die spoorstroombaan. Die stroom wat hier by die spoorstroombaan uitvloei, bestaan uit twee komponente. Die eerste hiervan $(I t)$ ontstaan as gevolg van induktiewe koppeling en word bereken deur die stroomverspreidingsmodel soos hierbo beskryf is. Indien daar aanvaar word dat die eienskappe van die twee aangrensende spoorbane dieselfde is, met ander woorde, die stroom in die trekkragspoor dieselfde is, kan die volgende vergelykings vir die ont vangkant neergeskryf word.

$$
I_{r k}-I_{i}+I_{1 b^{\prime}}-I_{i}+I_{1 r}
$$

Netso kan die randvoorwaardes by die bron as volg neergeskryf word:

$$
I_{s k}=I_{i}+I_{1 r^{\prime}}-I_{1 b}+I_{i}
$$

Met $\mathrm{l}_{\mathrm{th}^{\prime}}$ en $\mathrm{I}_{1 \mathrm{r}^{\prime}}$ die strome by die bron en ontvanger, in spoor $!$ van die aangrensende 
spoorstroombanc. Met behulp van hierdie voorwaardes kan die differensiaalvergelykings (38) tot (41) opgelos word en die steuringstroom wat deur die ontvanger vloei, bepalal word. Deur dieselfde prosedure te volg, kan die randvoorwaardes vir ander posisies van die lokomotief bepaal word.

\section{TOEPASSING VAN DIE MODELLE}

Soos voorheen genoem, is die modelle nodig vir die bestudering van die werking van die verskillende tipes spoorstroombane, sowel as vir die bestudering van steurings wat ontstaan as gevolg van moderne lokomotiewe.

So is die resultate wat in die studie verkry is, gebruik om 'n elektroniese ekwivalente van $1000 \mathrm{~m}$ spoorbaan mee te bou; die model word in die laboratorium gebruik wanneer loetse op verskillende tipes spoorstroombane gedoen word. Hierdie toetse is gewoonlik daarop gemik om 'n spesifieke probleem met 'n spoorstroombaan, wat in die praktyk net onder sekere omstandighede plaasvind, te ondersoek. Die ekwivalente spoorbaan is dan ook ontwerp om 'n spoorbaan met relatiewe hoë en/of relatiewe lae grondgeleidingsvermoě na te boots.

Alhoewel sinjaaltoerusting ontwerp word volgens faalveilige beginsels, gebeur dit van tyd tot tyd dat die toerusting na 'n onveilige toestand faal. In hierdie gevalle word 'n formele ondersock na die oorsaak van dic faling geloots. Wanneer so 'n faling deur steurings veroorsaak is, is dit baie moeilik om die presiese omstandighede in die praklyk te herkonstrueer, en word die spoorbaanmodelle gebruik. So is aangetoon dat indien sekere trekkragdeurverbindings van die spore verwyder word deur diefstal of watter rede ook al, pulserende strome in die spoor opgewek kan word deur 'n bewegende trein. Die harmonieke van hierdie pulserende strome kan dan ooreenstem met die frekwensie van sekere spoorstroombane, en 'n onveilige mislukking veroorsaak.

Tydens die studie is ' $n$ gerekenariseerde outomatiese meetopstelling ontwikkel om die spoorbaanparameters mee te meet. Sedertdien is gevind dat die meetopstelling ook handig gebruik kan word om die parameters van bane met moeilike operasionele probleme te ondersoek en op te los. Hierdie diens is ook al uitgebrei om sinjaalkabelparameters mee te meet.

\section{Summary}

Railway track circuits make use of the running rails as a transmission line to detect the presence of a train. Because of the irregular shape of the rail, the classical transmission line theory cannot be applied directly. An experimental method is discussed, whereby an equivalent round conductor can be found to replace the rail. This method divides the rail impedance into internal and external impedances. The internal impedance of the rail is a function of the material properties, rail current and temperature, while the external impedance is a function of the geometry of the line and the properties of the ground and ballast. This equivalent round conductor enables the use of the analytical expressions derived for the transmission line parameters of lines with round conductors. These expressions are used to calculate rail internal impedance, taking effects such as rail material properties, rail current, frequency and temperature into account. Measurement results obtained from tests on a test track are presented and used to verify the rail models, and the con- ductance and capacitance of the track

The application of the track impedance models is discussed in terms of models developed for the distribution of traction current. These models include a model for distribution of d.c. and a model for the distribution of a.c. traction current. These models are used to calculate the distribution between the conductors of the traction system and the earth. Experimental results obtained from a lest track are presented.

Secondly track circuit models, making use of track impedances derived are discussed. These models include an analytical track circuit transmission line model and a numerical track circuit model. The numerical model makes use of $A B C D$ transmission matrices and is ideally suited for implementation on a digital computer. These models are useful to study track circuit performance with varying earth and ballast conditions.

Calculation of traction current interference of a track circuit is also discussed. These models require the track circuit transmission line parameters and make provision lor various boundary conditions which may exist with different types of track circuits. The paper is concluded with a brief discussion of some of the applications of these models.

\section{LITERATUURVERWYSINGS}

I. Tso, S.K. et al. (1981). Attenuation effects of under-track reinforcing on automatic train protection signalling systems. IEE Proceedings $B, 128(2), 92-100$.

2. Comellini E. (1972). A computer program for determining electrical resistance and reactance of any transmission linc, IEEE Power Engineering Society, Summer Meeting, July, 308-3[4.

3. Trueblood, H.M., Washcheck, G. (1933). Investigation of rail impedances, Electrical Engineering, Dec., 898-907.

4. Schouten, J.P., V.d. Knaap, A., Kamstra, A.J. (1973). Study of the electrical characteristics of a track circuits, Oflice for Research and experiment (ORE). Question A25, Report 2, Oct., 1-131.

5. Hayt, W.H. (1974). Engineering electromagnetics. Third international student edition, (McGraw-Hill, New York, Kogakusha), Chapter 12: Transmission lines, 415-421.

6. Kennelly, A.E. (1916). Experimental researches on the skin elfect in steel rails, Journal of The Franklin Instinute, 182 (2), 135-191.

7. Royal Signals. (1957). Line transmission. In: Handbook of line communication, Royal Signals, London, Fourth impression, Chapter 16, 703-748.

8. Deri, A., Tevan, A. Semlyen, A., Castanheira, A. (1981). The complex ground return plane; A simplified model for homogeneous and multi-layer earth relurn, IEEE Transactions on Power Apparanis and Systems, 100 (8), 3686-3693.

9. Elcktriese taboratorium. Mect van spoorstaaf tot aardspannings op verskeic seksies, Elektriese laboratoritmverslag, (E.LAB) 19/80. (Johannesburg). 1-10.

10. Royal Signals. (1957). Mathematical treatment of line transmission. In: Handbook of line commumicatiom, Royal Signals. London, Fourth impression, Chapter 17, 749-763.

11. Tylavsky, D.J, (1985). Impedance of track/trolley haulage systems, Conference Record, IEEE Industry Applications Society Ammal meeting (Toronto), 206-212.

12. ORE. Specialists Committec A 122. (1979). Calculation of interference with track circuits due to electric traction. Question A/22, Report DT $9 /$ (Ollice for Research and Experiments of the international Union of Railways), 1-36.

13. Steyn B.M. (1987). Elektromagnetiese modelle vir elektriese spoorbaanstelsels van die Suid-A frikalanse vervoerdienste, M.Ing.verhandeling (Randse Alrikaanse Universiteit, Johannesburg) 181 pp. 